\title{
Comparison of myocardial protection methods in mitral valve surgery: a cohort study
}

\author{
Eduardo AV Rocha ${ }^{1,2}$, Lucas CD Pena ${ }^{1}$, Rafael A Carvalho ${ }^{2 *}$, Renato A Carvalho ${ }^{2}$, Thiago A de Castro ${ }^{2}$, \\ Mateus D Freire ${ }^{2}$ \\ From World Society of Cardiothoracic Surgeons 25th Anniversary Congress, Edinburgh \\ Edinburgh, UK. 19-22 September 2015
}

\section{Background/Introduction}

Myocardial protection is the group of strategies aimed at reducing ischemia-reperfusion lesions and its consequences. There is much discussion regarding different methods and their features, while there is no unanimity about which is most appropriate.

\section{Aims/Objectives}

We aimed to compare two types of myocardial protection, intermittent global ischemia and cold crystalloid cardioplegia, in patients submitted to mitral valve surgery: preoperative conditions and surgical or clinical outcomes. Furthermore, we aimed to calculate cardioplegia exclusive equipments' price.

\section{Method}

We performed a retrospective cohort study of medical records from patients who underwent mitral valve surgery at Hospital Universitário Ciências Médicas between 2010 and 2014. We compared preoperative conditions (gender, age and Euroscore II) and outcomes: death within 30 days, postoperative intensive care time and hospital stay time, cardiopulmonary bypass and ischemia time, use of pacemaker, use of vasoactive drugs and their time and intubation time. Cardioplegia equipments' total cost was calculated by indexation through three methods and thereafter the mean of its results.

\section{Results}

We found no differences between the two groups' preoperative conditions. The only difference between outcomes were cardiopulmonary bypass and myocardial ischemia time, in which the intermittent global ischemia

${ }^{2}$ Faculdade da Saúde e Ecologia Humana, Vespasiano, Minas Gerais, 33200000, Brazil

Full list of author information is available at the end of the article group was favored (Bypass: RR 0,19, 95\% CI: 0,09 - 0,41; Ischemia: RR 0,20, 95\% CI: 0,10 - 0,43). The mean price found for the cardioplegia equipment was $\mathrm{R} \$ 321,03$ (USD 101,12).

\section{Discussion/Conclusion}

Intermittent global ischemia presented shorter surgical duration and reduced mitral valve surgery costs, while it didn't affect mortality or morbidity. More comparative studies including other surgery types and different services are necessary to validate our results.

\section{Authors' details}

${ }^{1}$ Cardiovascular Surgery, Hospital Universitário Ciências Médicas, Belo Horizonte, Minas Gerais, 30140-073, Brazil. 'Faculdade da Saúde e Ecologia Humana, Vespasiano, Minas Gerais, 33200-000, Brazil.

Published: 16 December 2015

doi:10.1186/1749-8090-10-S1-A171

Cite this article as: Rocha et al:: Comparison of myocardial protection methods in mitral valve surgery: a cohort study. Journal of Cardiothoracic Surgery 2015 10(Suppl 1):A171.

Submit your next manuscript to BioMed Central and take full advantage of:

- Convenient online submission

- Thorough peer review

- No space constraints or color figure charges

- Immediate publication on acceptance

- Inclusion in PubMed, CAS, Scopus and Google Scholar

- Research which is freely available for redistribution 